$<$ 症例報告 $>$

ペースメーカー植込み患者の原発性肝細胞癌に対しバイポーラ電極針を用いた ラジオ波焼灼療法を施行した 2 例

\begin{tabular}{|c|c|c|c|c|c|c|c|}
\hline 伊集院 翔 ${ }^{12)}$ & 玉井 & 努 ${ }^{1) *}$ & 宇都 & 浩文 ${ }^{1)}$ & 大西 & 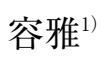 & 坂江 \\
\hline 織1) & 大﨡 & 彰彦1) & 小田 & 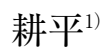 & 今中 & $大^{1)}$ & 熊谷公太郎 ${ }^{3)}$ \\
\hline 誠一1) & 森内 & 昭博1) & 桜井 & 一宏 ${ }^{2}$ & 堀 & 剛 ${ }^{3)}$ & 井戸 \\
\hline
\end{tabular}

要旨：症例 1 は 80 歳, 男性. 2007 年肝細胞癌に対して開腹下ラジオ波焼灼療法 (RFA) を施行 して以降, 多発再発に対して肝動注化学塞栓療法（TACE）にて繰り返し加療していた. 2013 年完全房室ブロックに対してペースメーカー植込み術が行われた. 2014 年 4 月肝 S4 の肝細胞癌 再発に対して,バイポーラ電極針 2 本にて RFA を施行した. 焼灼中はペースメーカー設定をVVI mode から VOO mode に変更した. 症例 2 は 86 歳, 男性. 2003 年完全房室ブロックに対してペー スメーカー植込み術が行われた. 2014 年 1 月肝 S6 の肝細胞癌に対して, TACE を施行後, バ イポーラ電極針 2 本にて RFA を追加施行した．焼灼中はペースメーカーの設定 (VDD mode) を変更しなかった. 2 症例共, 焼灼中に心電図モニ夕上に異常波形の出現は認めず, バイポーラ 電極針を用いた RFA は, ペースメーカー植込み症例でも安全に施行できると考えられた.

索引用語： バイポーラ電極針ラジオ波焼灼療法肝細胞癌電磁波障害 モノポーラ電極針

はじめに

近年, 肝細胞癌 (hepatocellular carcinoma：HCC)に 対するラジオ波焼灼療法 (radiofrequency ablation : RFA)に際して, モノポーラシステムに加えてバイポー ラRFA システム (CelonPOWER ${ }^{\circledR}$ ，オリンパス社) が 使用されるようになった.バイポーラ RFA システムで は，単針のみならず，複数針を用いてより広範囲の焼 灼が可能となり，また，腫瘍を直接穿刺せず，腫瘍を 挟み込む形で焼灼する non-touch ablation を施行するこ とで, 穿刺が非癌部を介せない肝表面に近接する HCC に対しても, 比較的安全に施行可能で, 腹膜焼灼など の合併症のリスク低減も期待されている1).

1）鹿児島大学大学院医歯学総合研究科消化器疾患 - 生 活習慣病学

2) 鹿児島莪信病院肝臓内科

3) 鹿児島市立病院消化器科

${ }^{*}$ Corresponding author:

tamaitsu@m.kufm.kagoshima-u.ac.jp

<受付日2014年7月22日 > <採択日 2014年12月21日 >
バイポーラ RFA システムは, 電流が RFA 電極針先 端に配置された $2 つ の$ 電極間のみを流れるため, 対極 板が不要である点が大きな特徵であり,ペースメーカー 植込み後で RFA 中の電磁波障害 (electromagnetic interference：EMI)が危惧される患者においても比較的 安全に使用可能と考えられる.

今回我々は, 完全房室ブロックに対し永久ペースメー カー植込み後の HCC 患者に対して,バイポーラ電極針 を用いて安全にRFA を施行した 2 例を経験したので報 告する.

\section{症例 1}

患者: 80 歳, 男性.

主訴：HCC の局所再発に対する治療目的.

既往歴：1996 年前立腺肥大・膀胱㮩室術, 2013 年 8 月完全房室ブロックに対してVVI 型ペースメーカー植 込み術.

輸血歴：1960 年頃輸血歴あるも詳細は不明.

現病歴：1990年頃 HCV 抗体陽性を指摘され,インター フェロン治療を施行されたが, ウイルスは陰性化しな 
Table 1 Laboratory data on admission

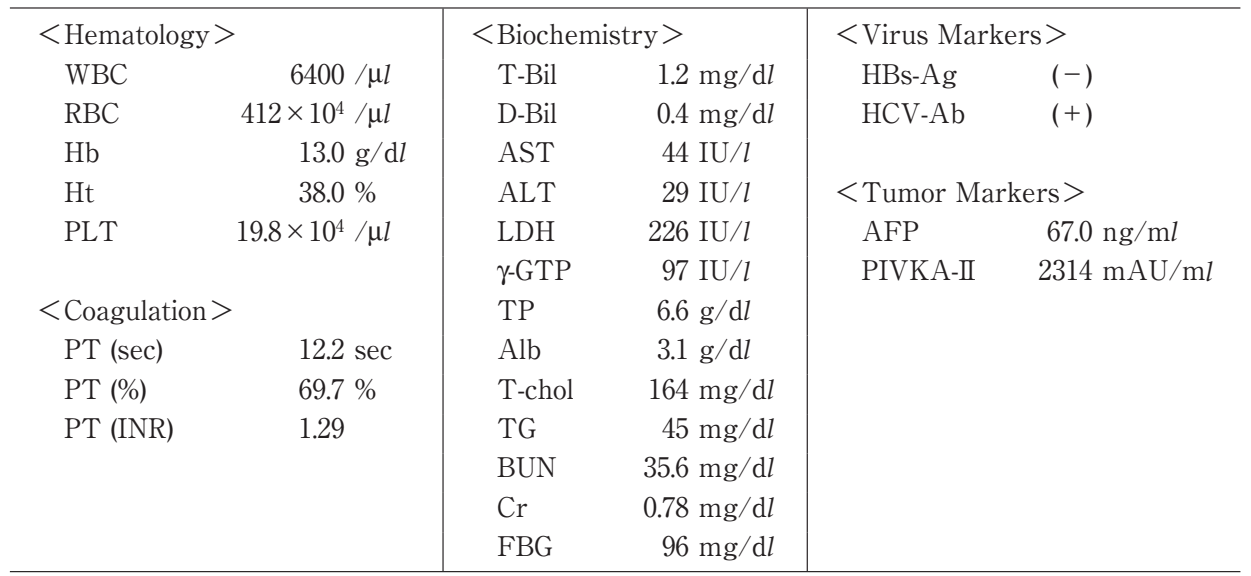
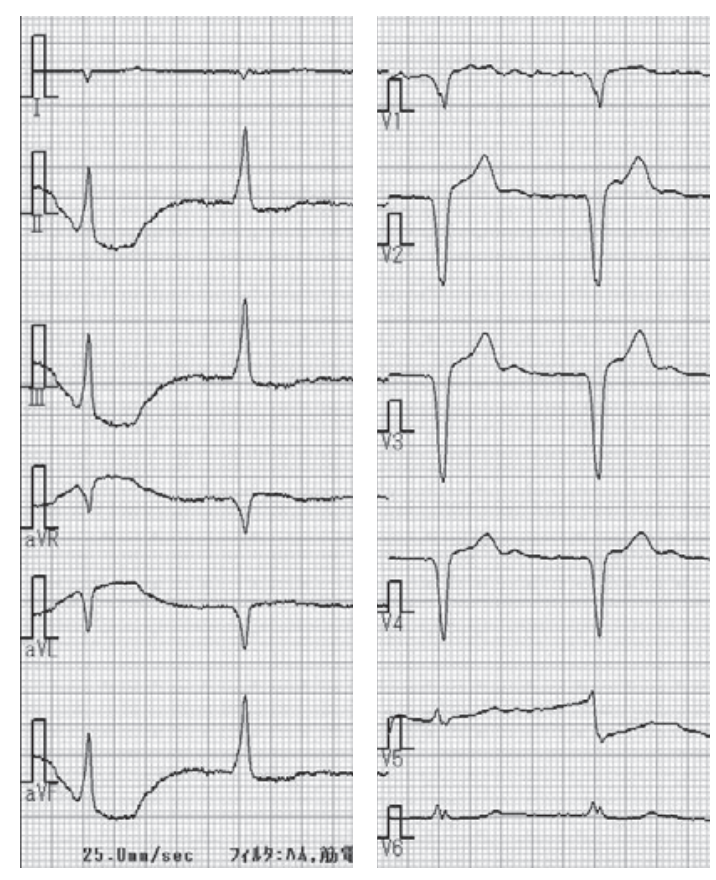

Fig. 1 12-lead electrocardiogram (ECG) on admission (Patient 1)

The ECG showed a paced rhythm in VVI mode (pacing rate 75 beats per minute).

かった. 2007 年 10 月, 肝 S 1 と S 8 に HCC を指摘され, 開腹下 RFA が施行された. 2008 年 6 月, C 型慢性肝炎 に対して, ペグインターフェロン及びリバビリン併用 療法が施行されたが, ウイルスは陰性化しなかった。
2010 年 11 月, HCC 多発再発に対して, 肝動脈化学塞 栓療法 (transarterial chemoembolization : TACE) が 施行された。その後も多発再発を認めたため, 2011 年 2 月よりソラフェニブの内服が開始され，2011 年 9 月より 2012 年 7 月まで, TACE (TACE 時にはソラフェ ニブを休薬する組み合わせ治療) が計 4 回施行された. 2014 年 4 月の腹部造影 CT 検查にて肝 S4 に HCC の局 所再発 (径 $21 \mathrm{~mm}$ ) を指摘され, 治療目的に入院となっ た.

入院時現症：胸部の大動脈弁領域に Levine III/VI 度の収縮期雑音を聴取. 右下肺野は呼吸音の減弱あり. その他の理学所見に異常なし.

入院時検査所見 (Table 1)：ALT は基準值内で, AST, ALP, $\gamma$-GTP は軽度高值であった. 腫瘍マーカーであ る $\operatorname{AFP}(67.0 \mathrm{ng} / \mathrm{ml})$ と PIVKA-II $(2314 \mathrm{mAU} / \mathrm{ml})$ は 高值であった. T-bil $1.2 \mathrm{mg} / \mathrm{d} l$, Alb $3.1 \mathrm{~g} / \mathrm{d} l$, PT $69.7 \%$ で, Child-Pugh score は 7 点で grade B であった.

入院時心電図 (Fig. 1) : ペースメーカー調律であっ た.

腹部超音波検査 : 肝 S4 に径 $20 \mathrm{~mm}$ の低一等輝度腫 瘍を認め, HCC 再発と考えられた。 その他, 肝内に治 療後と思われる結節を数力所認めた。

腹部造影 CT 検査: 肝 S4 に治療後と思われる low density area（LDA）を認め, その腹側の肝 S4に, 動 脈相で淡い早期造影効果を呈し (Fig. 2a), 門脈相・静 脈相で wash out がみられる径 $22 \mathrm{~mm}$ の腫瘍を認め(Fig. 2b), HCC 再発と考えられた. この腫瘍の中心部とペー シングリード先端の距離は $10.6 \mathrm{~cm}$ であった. また右側 

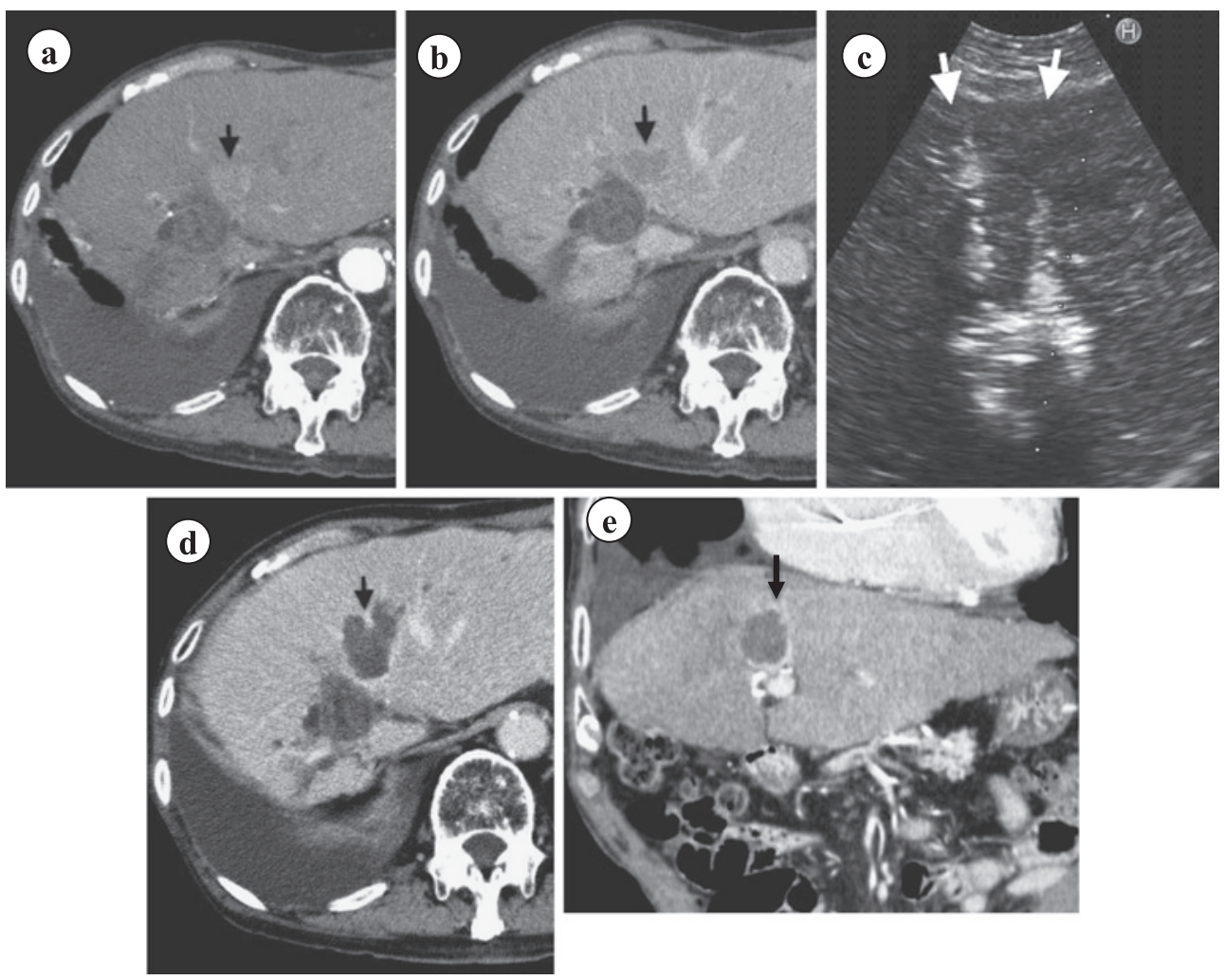

Fig. 2 Contrast-enhanced abdominal computed tomography and abdominal ultrasonography (Patient 1)

a: Before radiofrequency ablation (RFA): During the arterial phase of contrast-enhanced computed tomography, a hyperattenuated liver tumor measuring $22 \mathrm{~mm}$ was observed in segment 4 (black arrow), as well as a pleural effusion on the right.

b: During the venous phase of contrast-enhanced computed tomography, the liver tumor (black arrow) had low attenuation.

c: Abdominal ultrasonography immediately after ablation showed the tumor was punctured by two applicators in the direction of the white arrows.

d: After RFA: Contrast-enhanced computed tomography showed a ablated area (black arrow) had low attenuation including the liver tumor.

e: After RFA: Contrast-enhanced computed tomography showed an ablated area in coronal section image. The area was located cephalad to left portal vein, left hepatic artery and vein.

胸水貯留を認めた.

臨床経過：今回指摘された局所再発に対しては，こ れまで数回にわたり TACE を施行されたが,リピオドー ルは早期に wash out していた. 根治治療を目的として RFA を選択した. 今回はペースメーカー挿入後であっ たため,バイポーラ RFA システムを用いる方針とした. ペースメーカーの設定に関しては，ラジオ波を自己心 拍として感知しないよう, sensing を off とした.すな わち, 設定をVVI mode から VOO mode に変更した.
(ペースメーカーのモード設定は 1 文字目が刺激する部 位, 2 文字目が感知する部位, 3 文字目が応答様式を示 す. 刺激・感知する部位に関しては, A [atrial : 心房], $\mathrm{V}$ [ventricular : 心室], または $\mathrm{D}[$ dual : 両方 $=\mathrm{A}+\mathrm{V}]$ のいずれかで表し, 応答様式に関しては, T[triggered : 同期］, I [inhibited : 抑制]，または D [dual : 両方= $\mathrm{T}+\mathrm{I}]$ のいずれかで表す。また，刺激・感知を行わな い場合, 応答様式を設定しない場合は $\mathrm{O}[$ none : 無 $]$ で 表す.) 
Table 2 Laboratory data on admission

\begin{tabular}{|c|c|c|c|c|c|}
\hline \multicolumn{2}{|c|}{$<$ Hematology $>$} & \multicolumn{2}{|c|}{$<$ Biochemistry $>$} & \multicolumn{2}{|c|}{$<$ Virus Markers $>$} \\
\hline WBC & $2800 / \mu l$ & T-Bil & $1.2 \mathrm{mg} / \mathrm{d} l$ & HBs-Ag & $(-)$ \\
\hline $\mathrm{RBC}$ & $404 \times 10^{4} / \mu l$ & D-Bil & $0.3 \mathrm{mg} / \mathrm{d} l$ & HCV-Ab & $(+)$ \\
\hline $\mathrm{Hb}$ & $14.1 \mathrm{~g} / \mathrm{d} l$ & AST & $80 \mathrm{IU} / l$ & & \\
\hline $\mathrm{Ht}$ & $39.5 \%$ & ALT & $68 \mathrm{IU} / l$ & \multicolumn{2}{|c|}{$<$ Tumor Markers $>$} \\
\hline PLT & $10.5 \times 10^{4} / \mu l$ & $\mathrm{LDH}$ & $260 \mathrm{IU} / l$ & $\mathrm{AFP}$ & $83.3 \mathrm{ng} / \mathrm{ml}$ \\
\hline & & $\gamma$-GTP & $41 \mathrm{IU} / l$ & PIVKA-II & $26 \mathrm{mAU} / \mathrm{ml}$ \\
\hline \multicolumn{2}{|c|}{$<$ Coagulation $>$} & $\mathrm{TP}$ & $6.9 \mathrm{~g} / \mathrm{d} l$ & & \\
\hline PT (sec) & $10.9 \mathrm{sec}$ & Alb & $3.4 \mathrm{~g} / \mathrm{d} l$ & & \\
\hline PT (\%) & $95.9 \%$ & T-chol & $151 \mathrm{mg} / \mathrm{d} l$ & & \\
\hline \multirow[t]{4}{*}{ PT (INR) } & 1.03 & TG & $78 \mathrm{mg} / \mathrm{d} l$ & & \\
\hline & & BUN & $17.2 \mathrm{mg} / \mathrm{d} l$ & & \\
\hline & & $\mathrm{Cr}$ & $0.86 \mathrm{mg} / \mathrm{d} l$ & & \\
\hline & & FBG & $85 \mathrm{mg} / \mathrm{d} l$ & & \\
\hline
\end{tabular}

一方自己心拍が $45 \mathrm{ppm}$ 程度と低かったことから, 焼 灼中に起こりうる心拍出量低下を避けるため, basic rate を本来設定していた $60 \mathrm{ppm}$ から $80 \mathrm{ppm}$ に変更した. 先端焼灼範囲 $20 \mathrm{~mm}$ のバイポーラ電極針を 2 本使用し, 右肋弓下ょり, 腫瘍の左右辺縁を目標に逆八の字型に 穿刺した. 設定出力 $40 \mathrm{~W}$ にてバイポーラ RFA システ ムを用いて焼灼開始し (Fig. 2c), total 14.6 KJ, 12 分 5 秒で終了した．術中・術後に心電図モニ夕上は異 常波形の出現を認めず, ペースメーカー不全は生じな かった. 術後 5 日後の腹部造影 CT (Fig. 2d)にて, 腫 瘍辺縁の焼灼範囲がやや不十分であったが，門脈臍部 や左肝動・静脈に近接していたことによる, 冷却効果 が原因と考えられたため (Fig. 2e), 追加燒灼は施行し なかった．少なくとも治療終了後 6 力月後の腹部造影 CT では, 同部位に明らかな再発は認めていない.

\section{症例 2}

患者 : 86 歳, 男性.

主訴：肝腫瘍の精査・加療目的.

既往歴：2003 年 9 月完全房室ブロックにてVDD 型ペースメーカー植込み術.

輸血歴 : 不明.

現病歴：1999 年より C 型慢性肝炎を指摘され, 以後 経過観察されていた. 2012 年 5 月の腹部超音波検査に て肝内に高輝度腫瘍を指摘され, 血管腫として経過観 察されていた. 2013 年 11 月同腫瘍の増大と腫瘍マーカー の上昇があり，2014 年 1 月, 精査・加療目的にて紹介 入院となった.
入院時現症 : 胸腹部に異常所見はなかった.

入院時検査所見 (Table 2)：AST, ALT, LDH, ALP は高值で, 腫瘍マーカーは AFP $83.3 \mathrm{ng} / \mathrm{mL}$, PIVKAII $26 \mathrm{mAU} / \mathrm{ml}$ であった. また T-bil $1.2 \mathrm{mg} / \mathrm{d} l, \quad$ Alb 3.4 $\mathrm{g} / \mathrm{d} l$, PT $95.9 \%$ で, Child-Pugh score は 6 点で grade A であった.

入院時心電図 (Fig. 3) : ペースメーカー調律であっ た.

腹部超音波検査 : 肝 S5 に径 $22.3 \mathrm{~mm}$ の高輝度部分と 低輝度部分の混在した腫瘍を認めた。

腹部血管造影検査 : 経動脈性門脈造影下 CT (CT during arterial portography ; CTAP) では肝 S5 に径 $24 \mathrm{~mm}$ の門脈血流欠損像を認め (Fig. 4a), その他, 肝両葉の 末梢側に楔状の門脈血流欠損像を数力所認めた。肝動 脈造影下 CT (CT hepatic arteriography ; CTHA) で は, 肝 S5 の腫瘍は早期相で濃染し (Fig. 4b), 後期相 でややコロナ様に濃染が持続しており, HCC と診断し た. その他の門脈血流欠損部位は早期相で濃染するも, 後期相でコロナ様の造影効果は呈しておらず, 動脈-門 脈シャントと診断した. 腫瘍中心部とペーシングリー ド先端の距離は $18.1 \mathrm{~cm}$ であった.

臨床経過: 根治治療目的で TACE 施行後に RFA の方針とした．またペースメーカーが挿入されている 事から, バイポーラ RFA システムを用いた RFA を選 択した. 腹部血管造影検査後, 肝 S6 の HCC に対して, A6, A7 各々より miriplatin による TACE を施行した. RFA 時のペースメーカー設定に関しては, ペーシング リード先端と腫瘍中心部との間の距離が $18 \mathrm{~cm}$ と離れ 

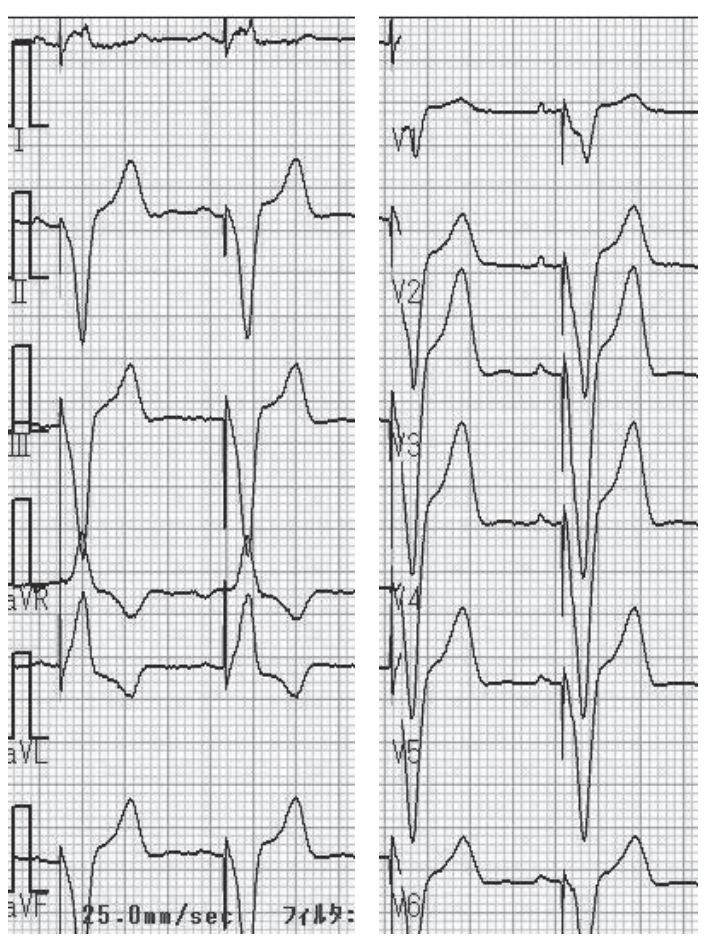

Fig. 3 12-lead electrocardiogram (ECG) on admission (Patient 2)

The ECG showed a paced rhythm in VDD mode (pacing rate 60 beats per minute).

ており, バイポーラ電極間を流れる電流をペースメー カーが誤って感知する可能性は低いと判断し，設定の 変更はせず，心電図モニ夕波形を注意深く観察する方 針とした. 2 本のバイポーラ電極針(先端 $30 \mathrm{~mm}$ 長)を 腫瘍の左右辺縁に逆八の字で穿刺し, 設定出力 $60 \mathrm{~W}$ にてバイポーラ RFA システムを用いて焼灼開始し(Fig. 4c), total $18.6 \mathrm{KJ}, 12$ 分で治療を終了した。術中およ び術後に心電図モニ夕上で異常波形の出現は認めず, ペースメーカー不全はなかった. 術後 3 日後の腹部造 影 CT（Fig. 4d）にて HCC 背側の焼灼範囲がやや不十 分であったが, 同部は先行した TACE によるリピオドー ルの集積が認められた事から，追加焼灼はせず，外来 にて定期的な画像検査を行い, 再発の有無を確認して いく方針として退院となった. 治療終了後 8 力月間, 同部位からの再発は認めていない.

\section{考察}

体外に発生した磁場による誘導電位により，心電位 信号に障害が生じることを電磁波障害(electromagnetic interference ; EMI) と呼ぶ233).これまでの RFA 針は, 内部冷却式電極いわゆる Cool-tip 型電極が中心で, モノ ポーラ電極であることから, 対極板の貼付が必須であ り, 電極と対極板の間には磁場が発生する事から,ペー スメーカー植込み患者に対して使用する際には，EMI が問題となる.

本邦においてペースメーカー植え込み患者の肝腫瘍 に対してモノポーラ電極を用いて RFA を施行した報告 は 2 例あり ${ }^{4) 5}$ ，その施行にあたっては，1)治療部と対 極板でジェネレーターを挟まないよう，対極板を両大 腿に貼付する，2）多大な電界を発生する RFA 装置を ペースメーカーから離れた位置に設置する，3)ペース メーカーの設定を適宜変更する, 4) 体外式除細動器の 待機的準備をする, などの工夫がされ，術中・術後に ペースメーカー不全は生じず, 安全にRFA を施行し得 ている.

一方, マイクロ波凝固療法 (microwave coagulation therapy；MCT)は, 電磁波を用いた HCC の局所療法 として知られている. EMI のうち, 一定以上の周波数 で, ペースメーカーのセンシング感度を上回る振幅の 雑音が規定時間以上連続して検出された場合, ペース メーカー設定が非同期モードに自動移行する現象があ り, MCT と同じ周波数 $(2450 \mathrm{MHz})$ を用いたマイク ロウェーブ温熱器による電磁波障害の検討では，一部 のペースメーカー機器で, $5 \mathrm{~m}$ 以内の距離で非同期モー ドへの自動移行を認めている. MCT でもモノポーラ電 極を用いた RFA においても,これまで国内外を含めて, ペースメーカー植込み患者の HCC に対する RFA 時に, EMI が発生したという報告はないが, ペースメーカー 植込み後の HCC 患者が少ない事や, 近年の HCC 患者 の高齢化により, RFA の適応であっても RFA を断念 し, TACE を選択する症例も想定されるため, 実際の EMI のリスクについては不明であり，むしろリスク回 避の点からは, 症例毎にきめ細かい対策と準備が必要 と考える.

一方，バイポーラ電極は，電気メスや消化管内視鏡 治療に抒ける止血・凝固の処置機器として以前より使 用されている. バイポーラ電極では, 電流は 2 つの電 極間でのみ流れるため, ペースメーカー植込み症例に おいて, バイポーラ電極を用いた RFA は EMIのリス クが低いと考えられている. 柴田らは,ペースメーカー 植込みをした雑種犬に対して，モノポーラスネアとバ イポーラスネアを用いて内視鏡的胃粘膜切除術を施行 

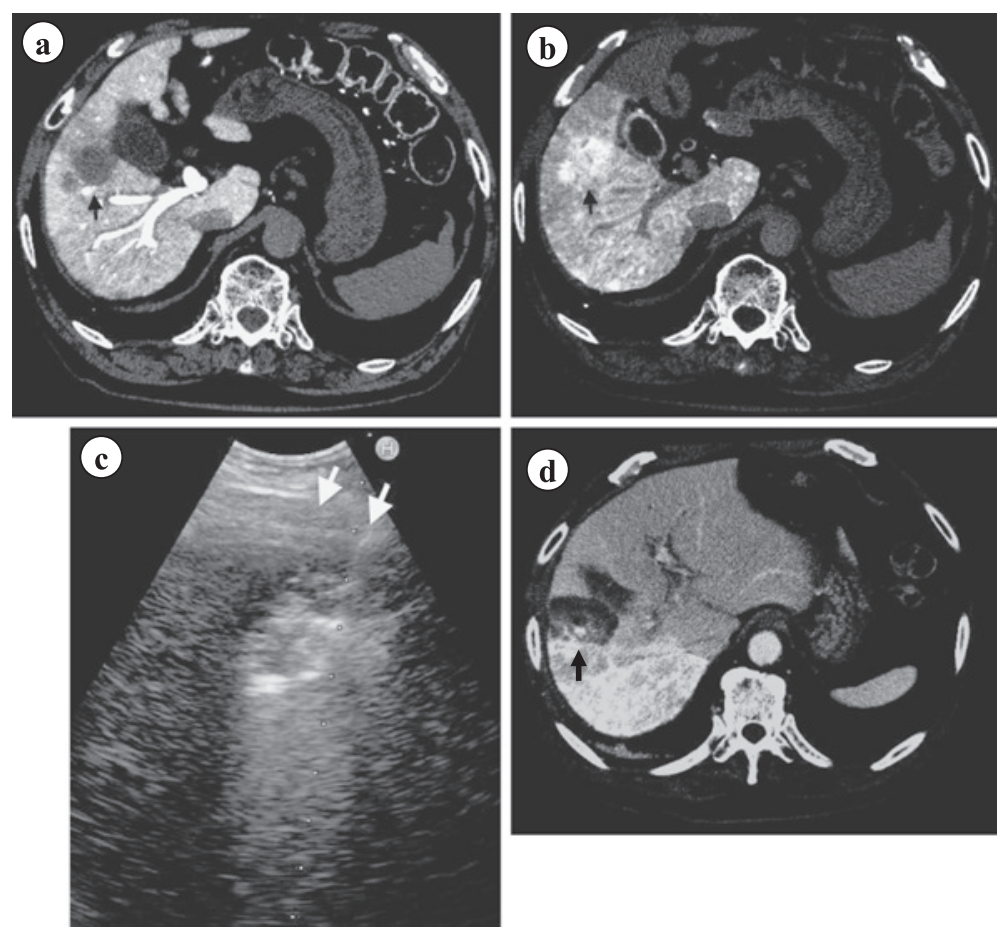

Fig. 4 Contrast-enhanced abdominal computed tomography and abdominal ultrasonography (Patient 2)

a: Computed tomography during arterial portography showed a hypoattenuated liver tumor in segment 5 (black arrow).

b: Computed tomography during hepatic arteriography showed a hyperattenuated liver tumor measuring $24 \mathrm{~mm}$ (black arrow).

c: Abdominal ultrasonography immediately after ablation showed the tumor was punctured by two applicators in the direction of the white arrows.

d: After transcatheter arterial chemoembolization (TACE) and RFA, contrast-enhanced computed tomography showed an hypoattenuated area with a collection of lipiodol in the posterior segment (black arrow).

し，バイポーラスネアがより心筋電極に対する干渉電 流が低くなることを示し, ペースメーカー植込み患者 に対して高周波電流を用いた内視鏡治療におけるバイ ポーラスネアの安全性を提言している6).

近年 HCC に対する新しいRFA デバイスとしてバイ ポーラRFA システム(CelonPOWER ${ }^{\circledR}$, オリンパス社) が使用可能となったが, ペースメーカー植込み患者の HCC に対してバイポーラ電極針を用いて RFA を施行 した報告はない.アメリカ麻酔学会によるペースメー カー・ICD 植込み患者の周術期管理の実践勧告7)には, 不整脈治療に用いる RFA（カテーテルアブレーション 治療）に関する項があり, 過去にカテーテルアブレー
ション治療にてペースメーカー不全を引き起こした報 告がある事から，アブレーションカテーテルとジェネ レーター及びリードとの直接接触を避けるだけでなく, ラジオ波回路がジェネレーター及びリードから可能な 限り離れるように調整することを推奨している，腫瘍 中心部からペーシングリード先端あるいはジェネレー ターまでの距離に関しては，これまでの報告はさまざ まであるが, 最大 $14 \mathrm{~cm}$ の症例においてもぺースメー カー不全は生じていない(4)58)99. EMI に対する対策の一 つとして, 2 症例とも RFA 装置の位置を, 患者の足側 右寄りにし, ペースメーカーのリード先端及びジェネ レーターからは $1 \mathrm{~m}$ 以上の十分な距離をとった. 
電気メスに関する報告において, 治療部位からジェ ネレーターまでの距離が $15 \mathrm{~cm}$ 以内でペースメーカー の設定変更を勧める報告 ${ }^{10)}$ や,バイポーラ電極にて軽微

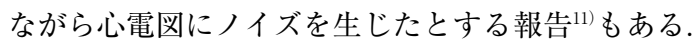

Mahlow らが提唱する, ペースメーカー及び ICD の周 術期管理のアルゴリズムをまとめた PACED-OP proto$\mathrm{Col}^{12)}$ では, フローチャートの最初に, 超音波検査, バ イポーラ電極, 超音波凝固切開装置は, ペースメーカー 管理の介入は不要であるが, それ以外の電磁機器では, ペースメーカーへの依存度や使用部位に基づいた, 厳 重なモニター管理やモード設定の変更が必要とされて いる. また, RFA 時のペースメーカーのモード設定に 関しては, ペースメーカーに対する依存度の高い症例 に拈いては, VOO, DOO などの固定レートへの設定変 更を行い，依存度の低い症例では，心拍数の設定を落 とし, 自己脈を出した状態でRFA を行うことを勧めて いる報告もある ${ }^{10)}$. 症例 1 は, pacing off の状態で心拍 数が $45 \mathrm{bpm}$ と低值であったため, ペースメーカーに対 する依存度の高い症例と考え, 術中はペースメーカー の設定をVOO モードに変更した. 術中・術後に心電図 モニター上で, 波形の乱れは認めず，ペースメーカー の機能不全はなかった. 本症例 2 に関しては, バイポー ラ電極針であることに加えて, 肝右葉の腫瘍中心から ペーシングリード先端までが約 $18.1 \mathrm{~cm}$ と十分な距離が あることから, EMIによりペースメーカーが誤作動を 起こす可能性は低いと考え, ペースメーカーの設定変 更は行わなかった. 術中・術後に EMI に起因するぺー スメーカーの機能不全は認めなかったが, リスクの観 点からは sensing off への設定変更が望ましかったので はないかと考えている.

バイポーラ RFA システムは, 従来のモノポーラ電極 である Cool tip 針を用いた RFA 装置と比較して, 複数 針による穿刺が可能である事から十分な凝固域が得ら れる点, 合併症が少ない点, 再発率が低い点などその 有効性, 安全性が報告されている ${ }^{1314)}$. しかしながら, ペースメーカー植込み患者に対するバイポーラ RFA システムを用いた HCC 治療の安全性については報告さ れていない.今回報告した 2 症例はいずれも EMIによ るペースメーカー不全等の合併症を起こすことなく, 安全に RFA が施行できたが, 今後のさらなる症例の蓄 積が必要と考えられた.

\section{結 語}

ペースメーカー植込み患者の HCC に対して,バイポー
ラRFA システムを用いて安全に治療を施行し得た 2 症例を経験した。 バイポーラ電極針を用いた RFA は, EMI のリスクは極めて低いと考えられた.

\section{文献}

1）辻 邦彦, 山崎 大, 永井一正, 他. Bipolar 型電 極による腹望鏡下 RFA が有用であった肝細胞癌の 1 例. 肝臓 $2013 ; 54: 819-825$

2) Irnich $W$. Interference in pacemakers. Pacing Clin Electrophysiol 1984; 7: 1021-1048

3) 水谷 登, 早稲田勝久, 加藤 勲, 他. 医療環境下 におけるペースメーカーと電磁干渉. 不整脈 $2000 ; 16: 541-546$

4) 向井章, 福田和人, 今井康陽, 他. ペースメーカー 植え込々患者の原発性肝細胞癌に対し経皮的ラジオ 波焼灼療法を施行した 1 例. 肝臓 2008；49：72一 76

5）吉田尚弘, 土山寿志, 増山聡子, 他. ペースメーカー 植え込み患者の転移性肝癌に対してラジオ波燒灼療 法を施行した 1 例。肝臟 $2006 ； 47 ： 147-151$

6) Hiroshi S, Mituyasu Y, Toshiya O, et al. Effects of High-frequency Current on Pacemakers during Endoscopic Gastric Surgery: Experimental Study. Dig Endosc 1999; 11: 150—157

7) American Society of Anesthesiologists. Practice advisory for the perioperative management of patients with cardiac implantable electronic devices: pacemakers and implantable cardioverterdefibrillators: an updated report by the American society of anesthesiologists task force on perioperative management of patients with cardiac implantable electronic devices. Anesthesiology 2011; 114: 247-261

8) Hayes DL, Charboneau JW, Lewis BD, et al. Radiofrequency Treatment of Hepatic Neoplasms in Patients With Permanent Pacemakers. Mayo Clin Proc 2001; 76: 950-952

9) Asensio EL, López TG, Guerrero MH, et al. Radiofrequency ablation of a hepatic neoplasm in a patient with an abdominal pacemaker. Cardiol J 2009; 16: $264-268$

10）大西佳彦、ペースメーカーおよび埋め込み型除細動 器装着患者に対する麻醉管理. 臨床麻酔 2006 ； $30: 981-987$

11）岡久稔也, 柴田啓志, 六車直樹, 他. ペースメーカー 装着患者に対する高周波を用いた内視鏡治療. 消化 
器内視鏡 $1996 ; 8: 563-570$

12) Mahlow WJ, Craft RM, Misulia NL, et al. A perioperative management algorithm for cardiac rhythm management devices: the PACED-OP protocol. Pacing Clin Electrophysiol 2013; 36: 238—248

13）恵荘裕嗣, 大崎往夫, 犬塚 義, 他. 肝癌に対する バイポーラ電極針を用いたラジオ波熱凝固療法〜当
院における初期使用経験〜.肝臓 $2013 ; 54$ : 577一 588

14) Yukio O, Kenji I, Namiki I, et al. Clinical effectiveness of bipolar radiofrequency ablation for small liver cancers. J Gastroenterol 2013; 48: 874-883

本論文内容に関連する著者の利益相反：なし

\title{
Two patients with pacemakers who safely underwent radiofrequency ablation with bipolar electrodes to treat primary hepatocellular carcinoma
}

\author{
Sho Ijuin ${ }^{122}$, Tsutomu Tamai ${ }^{1) *}$, Hirofumi Uto ${ }^{1)}$, Hiroka Onishi ${ }^{1)}$, Haruka Sakae ${ }^{1)}$, Kaori Muromachi ${ }^{1)}$, \\ Akihiko Oshige $^{1)}$, Kohei Oda ${ }^{1)}$, Dai Imanaka ${ }^{1)}$, Kotaro Kumagai ${ }^{3)}$, Seiichi Mawatari ${ }^{1)}$, \\ Akihiro Moriuchi $^{1)}$, Kazuhiro Sakurai ${ }^{2)}$, Takeshi Hori ${ }^{3)}$, Akio Ido ${ }^{1)}$
}

Patient 1 was an 80-year-old man with recurrent hepatocellular carcinoma (HCC). Previously, his HCC had been treated with transcatheter arterial chemoembolization (TACE) and radiofrequency ablation (RFA) using a monopolar electrode. In 2013, a pacemaker was implanted to treat complete atrioventricular block. In April 2014, he underwent RFA using two bipolar electrodes to treat recurrent HCC. During ablation, the pacing mode was changed from VVI to VOO. Patient 2 was an 86-year-old man who received a pacemaker for complete atrioventricular block in 2003. In 2014, he underwent TACE for HCC followed by RFA using two bipolar electrodes. The pacing mode (VDD) was not changed during ablation. In both patients, we did not observe any abnormal waveforms with electrocardiographic monitoring or pacing failure during ablation. These results suggest that treating HCC using RFA with bipolar electrodes is safe in patients with pacemakers.

Key words: bipolar electrodes radiofrequency ablation hepatocellular carcinoma electromagnetic interference monopolar electrode

Kanzo 2015; 56: 57-64

1) Digestive Disease and Life-style Related Disease, Kagoshima University Graduate School of Medical and Dental Sciences, Japan

2) Department of Hepatology, Kagoshima Teishin Hospital

3) Department of Gastroenterology, Kagoshima City Hospital

*Corresponding author: tamaitsu@m.kufm.kagoshima-u.ac.jp 